\title{
Микола МОГА
}

кандидат педагогічних наук,

докторант кафедри ортопедагогіки, реабілітології та ортоспихології

Київського національного державного педагогічного університету ім. М.П. Драгоманова, м. Київ, Україна e-mail: moga2003@ykr.net

\section{ГАРМОНІЗАЦІЯ М'ЯЗОВО-ФАСЦІАЛЬНОЇ СИСТЕМИ ДІТЕЙ РАННЬОГО ВІКУ ЗІ СПАСТИЧНИМ СИНДРОМОМ РУХОВИХ ПОРУШЕНЬ}

У статті детально розглянуто третій умовний корекційний вектор загальної авторської реабілітаційної стратегії відносно дітей раннього віку зі спастичним синдромом рухових порушень - методичні можливості гармонізації їхньої м'язово-фасціальної системи. Попередньо було проаналізовано стан головних парних міофасціальних ліній через призму спастичного синдрому: поверхневої фронтальної лінії, поверхневої задньої лінії, двох латеральних ліній, двох спіральних ліній, двох парних ліній рук.

За основу корекції стану м'язового дисбалансу на фоні наявного спастичного синдрому було взято діагонально-фасціальну гімнастику (ДФГ) Пака Дже Ву, за допомогою якої гармонізується стан м'язів антагоністів. Головними техніками цієї методики є почергове розтягування м'язів, їхнє стискання, а потім скручування за діагональними напрямками у різних сегментах тіла при чередуванні з централь ними, серединними напрямками корекційних впливів. Такий підхід нагадує спіралеподібні рухи, що $\epsilon$ універсальною структурною моделлю розвитку життя.

Базові методичні положення ДФГ було адаптовано відповідно до рішення завдань корекції рухових порушень спастичного типу у дітей саме раннього віку на основі бондінгових технік та необхідної театралізації процесу корекції. Саме це унікальне сполучення дає змогу у значній мірі подолати наявний у дітей цього віку жах перед тілесними маніпуляціями та больовий синдром, що при цьому виникає. Додатково було застосовано вібраційно-хвильову техніку вправ для вдосконалення м'язів. За допомогою адаптованого варіанту діагонально-фасціальної гімнастики можливо досягти більш високого ступеня ефективності корекції наявних рухових порушень спастичного типу.

Перспективи дослідження цієї проблеми знаходяться у руслі пошуку нових технічних прийомів адаптування ДФГ до фізичної реабілітації дітей раннього віку у поєднанні з тілесним бондінговим фоном та на основі емоційно-енергетичної насиченості рухово-ігрової діяльності.

Ключові слова: рухові порушення, м'язово - фасціальна система, діагональна гімнастика, корекція, гармонізація.

Для гармонізації стану м’язово-фасціальної системи людини протягом останнього століття розроблено чимало методик [1 - 10], які дійсно працюють і завдяки яким можна отримувати достатньо ефективні результати. Але переважна більшість 3 них розроблена для психофізичної реабілітації дорослих людей, які можуть проявляти значні вольові зусилля щодо подолання наявних у них проблем з опорно-руховим апаратом, які можуть в достатній мірі терпіти біль, що виникає при корекційних маніпуляціях у проблемних м'язах. Коли мова йде про дітей раннього віку, виникає чимало проблем із застосуванням навіть відомих світових методик, бо мала дитина ще не може свідомо реалізовувати свою волю і дуже чутлива до фізичного дискомфорту, що може виникнути під час корекційної роботи з м'язами. Це робить актуальним пошук варіантів адаптації існуючих методик гармонізації стану скелетном'язових утворень відповідно до дітей раннього віку зі спастичним синдромом рухових порушень.

Метою статті $\epsilon$ попередній пошук варіантів адаптації діагонально-фасціальної гімнастики
(ДФГ) Пака Дже Ву та його послідовників відповідно до дітей 1 - 3 років зі спастичним типом рухових порушень 3 метою гармонізації їхньої м'язово-фасціальної системи.

Говорячи про необхідність гармонізації стану м'язів у дітей зі спастичним синдромом, необхідно зазначити цікавий та достатньо ефективний підхід, який спостерігається у діагональнофасціальній гімнастиці відомого південнокорейського професора Пака Дже Ву [10]. На прикладі найбільш відомого комплексу вправ наведемо основні положення цієї гімнастики, яка спрямована на нормалізацію і покращення роботи м'язів-антагоністів, в яких з різних причин порушено необхідний реципрокний баланс.

Комплекс виконується у вихідному положенні лежачи на підлозі, попередньо підстеливши складену у кілька разів ковдру, або на масажній кушетці чи ліжку. При необхідності треба підкласти подушку або валик під поперек та під шию. Нам підходить таке вихідне положення, бо це співпадає з нашим баченням методології та методики фізичної реабілітації осіб з порушеннями 
опорно-рухового апарату, а саме - з еволюційнім методом вправляння, та первинністю релаксації відносно напруження. Саме стартове лежаче положення і віддзеркалює таких підхід.

Після цього необхідно діагонально розтягувати хребет і тулуб від лівого плеча до правого тазостегнового суглоба, прогинаючись назад (рис. 1). Тягнутися потрібно всім тілом, відчуваючи, як за хребтом розтягуються грудна клітка, черевна порожнина, всі органи, нерви, судини. Не потрібно намагатися робити розтягнення з максимальною силою і амплітудою - робіть розтягування так, якби ви хотіли потягнутися обмежуючи себе. Спільна робота м'язів - агоністів, що розтягують, i антагоністів, які перешкоджають розтягуванню, створює необхідний терапевтичний ефект. Виконуючи розтягування, додаємо також невелике скручування хребта вздовж осі так, щоб ліве плече поверталося наліво, а праве стегно і таз - направо. Утримуємо себе в такому розтягнутоскрученому положенні чотири секунди. Повертаємося в початкове положення і виконуємо діагональне розтягнення від правого плеча до лівого тазостегнового суглоба. Супроводжуємо розтягнення скручуванням по осі. Утримуємо положення чотири секунди.

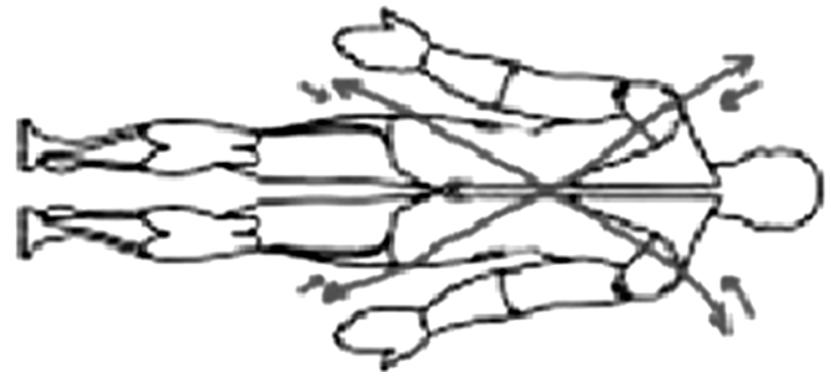

Рисунок 1

Слід сказати, що така техніка самостійного виконання цієї вправи неможлива, якщо говорити про дитину раннього віку, але саме у такої дитині м'язово-фасціальний комплекс ще вельми м'який, пластичний і гарно піддається коригуванню. Тому, на нашу думку, активне виконання цієї вправи треба замінити на пасивне, примусове, коли рухи за дитину в значній мірі робити саме педагог, виконуючи необхідні розтягування.

Виконавши розтягнення, приступаємо до стиснення. Виконуємо діагональне стиснення від лівого плеча до правого тазостегнового суглоба. Намагаємося якби з'єднати ці дві крайні позиції, скластися. Стиснення супроводжується скручуванням по осі хребта, при цьому ліве плече розгортається направо, а праве стегно - наліво. Таким чином, плече і тазостегновий суглоб рухаються до серединній лінії. Стиснення також не потрібно робити з максимальною силою - досить використовувати 1/3 зусилля, активізуючи роботу протилежних м'язів-антагоністів, щоб частково утримати тіло від максимального стискання, балансувати на межі між стисненням і розтягненням. Утримуємо положення 4 секунди. Повертаємося до нейтрального положення. Виконуємо стиснення i скручування від правого плеча до лівого тазостегнового суглоба. Утримуємо чотири секунди.

Виконавши комплекс діагонального розтягування-стиснення, починаємо виконувати розтягнення-стиснення по центральній осі (рис. 2). У цьому фрагменті методики Пака Дже Ву нас цікавить те, що зусилля при стисканні на суглоби повинні бути максимальними і дорівнювати $1 / 3$ від максимуму. Це дуже вдало підходить для корекційних маніпуляцій з дітьми саме раннього віку, вельми чутливих до механічних подразнень на їхнє тіло.

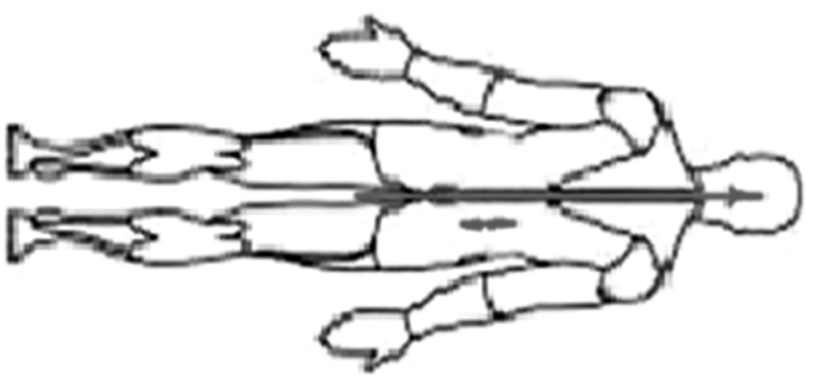

Рисунок 2

Перебуваючи в лежачому вихідному положенні, необхідно повільно розтягувати хребет і все тіло від крижня до плечей та верхньогрудного відділу хребта. Тут не треба робити ніяких скруток і нахилів - має працювати тільки центральна вісь. Стримуємо максимальне розтягування, використаючи дію м'язів-антагоністів, які запобігають надмірному розтягненню. Виконувати вправу чотири секунди. Після розтягування треба виконати стиснення. Не відриваючи таза і спини від поверхні, намагаємося частково стиснути хребет, наближаючи точки крижня і сьомого шийного хребця. Частково перешкоджаємо максимальному руху роботою м'язів-антагоністів, що розтягують хребет. Виконувати вправу чотири секунди.

Для дитини 1-3 років ця техніка ще більш складна для виконання, майже неможлива, тому має активізувати свої мануальні зусилля корекційний педагог і робити це необхідно у положенні дитини лежачи на животі, щоб була змога натискати однією рукою (наприклад, лівою) на ділянку крижня, а іншою (правою) на сьомий шийний хребець.

Після розтягування-стиснення по осі починаємо виконувати восьмиподібні рухи тулубом. По черзі напружуючи м'язи, рухаємося від лівого плеча вниз по діагоналі до зони на ширину долоні 
нижче лопаток (область переходу грудного відділу хребта в поперековий, зона діафрагми), далі, продовжуючи рух по діагоналі, до правого тазостегнового суглобу, від якого через крижень рухаємося до лівого тазостегнового суглобу, потім піднімаємося по діагоналі вгору до зони переходу грудного відділу хребта в поперековий і ще вище до правого плеча; завершуючи цикл, переходимо від правого плеча через зону 7-го шийного хребця до лівого плеча. Ці рухи нагадують повну замкнуту вісімку (Рис. 3 А, Б). Рухи мають бути подібними плавному пересуванню умовної змії. В них закладено три компоненти: стиснення, розтяг i скручування. Повільно виконати чотири повних 8-подібних циклів, починаючи від лівого плеча до правого тазостегнового суглобу, далі зробити чотири повних вісімки в протилежному напрямку від правого плеча до лівого тазостегнового суглобу. Після виконання пацієнту треба полежати кілька секунд та відпочити.
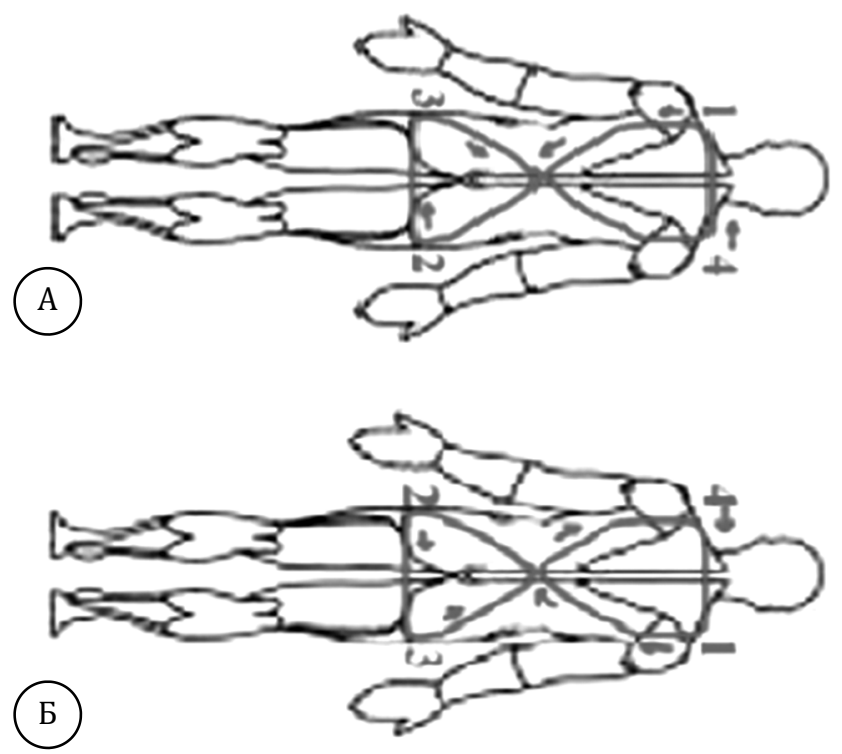

Рисунок 3

Стає зрозумілим, що дитина раннього віку самостійно не в змозі виконати таку складну за реалізацією вправу, тому тут знов активізує свою мануальну діяльність саме педагог. Крім мануального втручання він має активізувати і ігровий компонент вправляння, придумавши відповідний сюжет с захоплюючими дитину колізіями. Це може бути умовний робот Файник, що допомагає матусі дитинки прати білизну, то розтягуючи ï, то стискаючи, то викручуючи, щоб віджати воду.

Після виконань вправ на рівні тулуба за рекомендацією автора методики ДФГ треба перейти до вправ для ніг, рук, шиї та обличчя. Нас трохи бентежить така рекомендована послідовність, бо в ній ми спостерігаємо порушення одного з головних в біологічному становленні людини принци- пу - цефалокаудального, яким передбачається послідовне формування анатомо-фізіологічних структур організму в одному напрямку: від тім'ячка до п'ят. Саме голова та шия у новонародженої дитини починають першими формувати необхідні рухові патерни, після чого до них приєднуються м'язи та суглоби плечового поясу та верхніх кінцівок, тулуба і т.д. Тому ми вважаємо за необхідне рекомендувати педагогам виконувати елементи ДФГ саме з вправ для голови та шиї, а не $з$ тулуба або кінцівок.

Принципи виконання вправ для рук і ніг аналогічні вправам для тулуба. Виконуються ті ж вісім етапів - два розтягування, два стискування, дві вісімки в одну сторону і дві в іншу. Існують два варіанти виконання вправ для кінцівок. У першому варіанті ми розтягуємо і стискуємо від внутрішньої частини стегна (або плеча) до зовнішньої частини стопи (або кисті), потім від зовнішньої частини стегна (плеча) до внутрішньої частини стопи (кисті) (мал. 4). Таким чином в рух втягується вся кінцівка. У другому, більш складному варіанті, рухи виконуються послідовно - спочатку для гомілки (передпліччя), потім для стегна (плеча). Таким чином, нога і рука діляться на незалежні дві частини, для яких виконується повний цикл вправ. У такому підході, запропонованому південнокорейським вченим, ми також помічаємо порушення одного із фундаментальних правил розвитку та корекції кінцівок людини від центру до периферії, від проксимальних відділів кінцівок (близько розташованих до тулуба) до дистальних (віддалених від тулуба). У зв'язку з цим ми пропонуємо змінити послідовність вправляння на біоланках верхніх та нижніх кінцівках, починаючи, відповідно, з плеча, а потім переходити на передпліччя, а в ногах - починаючи із стегна 3 переходом на гомілку. Перший варіант $\epsilon$ загальнооздоровчим, а другий застосовується при виражених проблемах в області виконання гімнастики, для більш детального опрацювання м'язів і кісток рук і ніг.

Розглянемо 1-й варіант. Вихідне положення лежачи. Руки розвернуті долонями вгору. Починаємо гімнастику з лівої руки. Виконуємо розтягнення і проти скручування від внутрішньої частини лівого плеча (область пахової западини) до зовнішньої поверхні лівого променево - зап'ясткового суглоба (область основи великого пальця). Затримуємося на чотири секунди. Тепер розтягнення і проти скручування виконуються від зовнішньої частини лівого плеча до внутрішнього краю лівого променево - зап'ясткового суглоба (область мізинця). Затримуємося на 4 секунди. Виконавши розтягування в тій же послідовності, виконуємо стиснення. Далі мають бути розтягнення-стиснення по 
серединній осі руки, кисть знаходиться в нейтральному положенні, долонею догори. 3 огляду на те, що виконати восьмиподібний рух руки досить складно, у наступній вправі необхідно повільно виконати чотири колових оберти руки назовні 3 активним рухом в плечовому, ліктьовому та променево-зап'ястковому суглобах і чотири оберти всередину.

Закінчивши вправлятися, потрібно кілька секунд додати змогу відпочити, а потім приступити до вправи для правої ноги. Виконуємо розтягнення і проти скручування від внутрішньої поверхні правого стегна (пахова область) до зовнішньої поверхні правого гомілковостопного суглоба (у напрямку до мізинця). Затримуємося на чотири секунди. Тепер розтягнення і проти скручування виконуються від зовнішньої частини правого стегна до внутрішнього краю правого гомілковостопного суглоба (у напрямку до великого пальця). Затримуємося на чотири секунди. Виконуємо стиснення в тій же послідовності. Тепер необхідно робити розтягнення-стиснення по серединній осі. Далі - кругові рухи в тазостегновому, колінному і гомілковостопному суглобах: чотири циклу у напрямку назовні і чотири циклу у напрямку всередину. Зробити відпочинок. Тепер виконуємо подібні вправи для лівої ноги і далі для правої руки. (рис. 4).

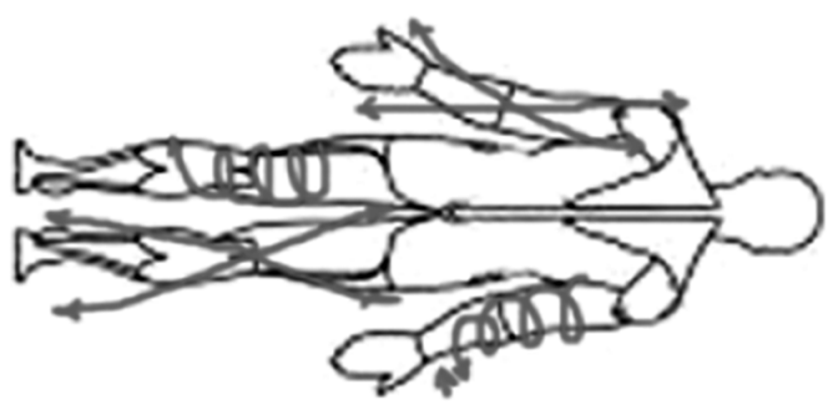

Рисунок 4

Після рук і ніг починаємо роботу з шиєю. Зберігати теж саме вихідне положення лежачи, але під голову треба покласти подушку. Починаємо розтягуватися і скручуватися від лівого вуха до правого плеча (рис. 5).

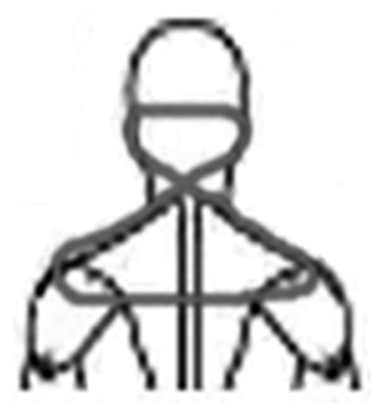

Рисунок 5
Виконуємо вправу повільно, акуратно, без надмірних зусиль, контролюючи розтягнення стисненням м'язів-антагоністів. Якщо при розтягуванні відчувається бар'єр або неприємне відчуття, зупиняємося і трохи зменшуємо амплітуду. Затримуємося на чотири секунди. Виконуємо розтягнення від правого вуха до лівого плеча і знову чотири секунди фіксації. Тепер стиснення: від лівого вуха до правого плеча, потім - від правого вуха до лівого плеча. Затримка по чотири секунди. Виконавши діагональні розтягуваннястиснення, виконуємо розтягнення-стиснення по серединній осі. Аналізуючи запропоновану автором ДФГ методику, нам здається не зовсім вірною послідовність «від діагональних вправлянь - до центральних вправлянь». На нашу думку, в онтогенетичному розвитку дитини передують саме центрально-симетричні рухи головою, кінцівками і тулубом і лише потім, по мірі формування необхідних міжкулькових координаційних нейронних шляхів, актуалізуються перехресні асинхронні координаційні моторні патерни. Саме тому ми рекомендуємо змінити послідовність вправляння, віддавши першочергову перевагу центральним рухам у всіх біоланках тіла, а вже потім вправлятися за принципом діагоналі та спіралі. У графічному вигляді це можна представити таким чином (рис. 6).

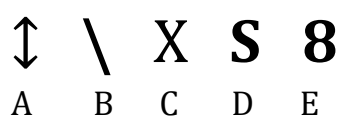

Рисунок 6

Далі приступаємо до руху по вісімці аналогічно руху в області тулуба. Від лівого вуха рухаємося до правого плеча, від правого плеча до лівого, від лівого плеча до правого вуха. Центр перехрещення припадає приблизно на середину шиї. Виконавши чотири цикли, робимо рухи від правого вуха до лівого плеча, від лівого плеча до правого плеча, далі до лівого вуха. Повільно виконуємо чотири цикли з відпочинком наприкінці.

Завершуємо комплекс гімнастики ДФГ виконанням вправ для обличчя. На наш погляд, саме 3 обличчя потрібно починати робити вправи ДФГ, бо перші умовні м'язові панцирі формуються саме навколо очей та оральної зони. Якщо їх не зняти першими, це напруження буде передаватися нижче розташованим панцирам, шийному та плечовому. Розтягування-стискування і восьмиподібні рухи на обличчі виконуються за допомогою саме мімічної мускулатури. Починаємо розтягнення від лівого ока (ліва брова, ліва частина чола) до правого кута рота (права частина нижньої щелепи, шия праворуч). Для розтягування необхідно 
підняти брову і напружити лобові м'язи зліва, опустити кут рота і напружити щелепно-лицьові м'язи справа. Затримуємо положення протягом чотирьох секунд. Далі виконуємо вправу від правого ока до лівого кута рота, потім стискування від лівого ока до правого кута рота, затримка у кінцевому положенні на чотири секунди. Виконуємо вправу стискування за умовною діагоналлю «праве око - лівий кут рота». Чим більше лицьових м'язів з кожного боку буде задіяно у вправі тим краще. Тепер виконуємо розтягнення лицьових м'язів по серединній осі - піднімаємо брови вгору, збираємо лобові складки, відкриваємо рот і опускаємо вниз щелепу. Затримка протягом чотирьох секунд. Далі йде стиснення завдяки тому, що стискаємо брови, стуляємо щелепу, морщимо ніс. Затримка чотири секунди. Виконуємо восьмидібний рух - поперемінно напружуємо м'язи обличчя від лівого ока вниз до правого кута рота (в русі залучаються м'язи щік, носа), далі від правого кута рота - до лівого (рух щелепи, підборіддя), від лівого кута рота до правого ока, від правого ока, через, до лівого ока: чотири цикли в один бік і чотири цикли в зворотній послідовності. Після цього зробити відпочинок. Зрозуміло, що мала дитина зі спастичним синдромом рухових порушень не зможе самостійно зробити ці вправи для обличчя, тому рекомендуємо замінити їх на масаж відповідних лицьових м'язів у запропонованих діагональновосьмиподібних напрямках. Закінчивши вправи для обличчя, треба дати дитині полежати трохи у розслабленому положенні для відновлення.

На нашу думку, до головних рухів ДФГ треба додати гармонізуючий хвилеподібний рух за системою цілісного хвильового руху (СЦР) М.И. Кудряшова. Саме хвилеподібний рух, на його думку, гармонізує відносини між м'язами- антагоністами, знімаючи механічні та енергетичні перешкоди на шляху умовної рухової хвилі.

Підводячи підсумки аналізу та можливості адаптування запропонованої Паком Дже Ву діагонально-фасціальної гімнастики, можна зробити такі попередні висновки:

1. Більшість існуючих методик гармонізації м'язово-фасціального стану людини передбачена для дорослих чоловіків та жінок, в тім корекційна робота по подоланню наслідків спастичного синдрому у малюків потребує значного їх адаптування у відповідності до особливостей психофізичного розвитку дітей 1 - 3 років.

2. Найбільш вдалою для гармонізації стану м'язово-фасціальних утворень вважаємо діагонально-фасціальну гімнастику Пака Дже Ву, та його послідовників-інтерпретаторів.

3. Виходячи 3 аналізу основних методичних позицій цієї гімнастики та відштовхуючись від багаторічного особистого досвіду корекційної роботи з такими дітьми, пропонуємо деякі зміни у цій технології, які зазначимо нижче: замінити активне виконання гімнастики на пасивне з допомогою педагога; починати гімнастику треба не з тулуба, а, за цефалокаудальним принципом, з голови (обличчя та шиї), потім перейти на руки, далі тренувати м'язово-фасціальний комплекс тулуба i лише наприкінці робити маніпуляції на нижніх кінцівках; топографію вправляння замість запропонованої змінити на таку: прямолінійні центральні рухи, діагональні рухи, перехресні рухи, вісімко подібні хвильові та спіралеподібні рухи.

Перспективи дослідження цього цікавого напряму вбачаємо в удосконалені мануальнорухових впливів на дитину раннього віку у поєднані 3 казковою сюжетністю театралізованого методу.

\section{Список використаних джерел}

1. Єфименко М. М. Методичні можливості психосоматики В. Райха в корекції рухових порушень у дітей / М. М. Єфименко // Вісник Луганського педагогічного університету імені Т. Г. Шевченка. Сер.: Освіта та педагогічна наука. - Луганськ, 2012. - №3(152). - С. 19 - 23.

2. Ефименко Н. Н. Методические феномены релаксации и напряжения в двигательной реабилитации детей / Н. Н. Ефименко // Педагогика, психология и медико-педагогические проблемы физического воспитания и спорта. Харьков, 2013. - №2. - С. 22 - 27.

3. Ефименко Н. Н., Беседа В. В. Малый театр физического развития и оздоровления детей младенческого и раннего возраста : учебно-методическое пособие. Изд-е 4-е, доп. и перераб. / Н.Н. Ефименко, В.В. Беседа. - Винница: Твори, 2018. - 252 c.

4. Хохлов А.П. с соавт. Диагональная гимнастика для детей и взрослых с церебральной патологией / А.П. Хохлов, 0.П. Тараканов, А.Н. Доценко // Учебно-методическое пособие М.: Центр Современной медицины «Примавера медика», 1996. - 16 с.

5. Чикуров Ю.В. Мягкие мануальные техники. Изд-е 3, доп. / Ю.В. Чикуров. - М.: Триада-Х, 2018. - 176 с.

6. Alexander F. The resurrection of the body / F. Alexander. - New York : Dell (Delta books), 1969. - $234 \mathrm{p}$.

7. Lowen A. Bioenergetic analysis : a mind-body therapy / A. Lowen, J. Zeig ed. // The evolution of psychotherapy. - New York, 1992.

8. Rolf I. P. Rolfing : the integration of human structures / I. P. Rolf. - Santa Monica : Denis-Landman, 1977.

9. Upledger J. E. Craniosacral Therapy / J. E. Upledger, J. D. Vredevoogd. - New York : Eeasland Press, 1983. - 367 p.

10. Режим доступа: http://www.osteodoc.ru/dfg.htm. 


\section{References}

1. Efimenko M. M. (2012). Metodichni mojlivosti psihosomatiki V. Raiha v korekciï ruhovih porushen u ditei [Methodical possibilities of V. Reich's psychosomatics in correction of motor disorders in children]. Lugansk, vol. №3 (152). - S. 19 - 23. [in Ukrainian].

2. Efimenko N. N. (2013). Metodicheskie fenomeni relaksacii i napryajeniya v dvigatelnoi reabilitacii detei [Methodical phenomena of relaxation and stress in motor rehabilitation of children]. Harkov, vol. №2. - S. 22 - 27. [in Ukrainian].

3. Efimenko N. N., Beseda V. V. (2018). Malii teatr fizicheskogo razvitiya i ozdorovleniya detei mladencheskogo i rannego vozrasta [Small theater of physical development and rehabilitation of infants and young children]. Vinnica: Tvori, $252 \mathrm{~s}$. [in Ukrainian].

4. Hohlov A.P. s soavt. (1996). Diagonalnaya gimnastika dlya detei i vzroslih s cerebralnoi patologiei [Diagonal gymnastics for children and adults with cerebral pathology]. Moskva: Centr Sovremennoi medicini «Primavera medika», 16 s. [in Russian].

5. Chikurov Yu.V. (2018). Myagkie manualnie tehniki. [Soft manual techniques]. Moskva: Triada-H, 176 s. [in Russian].

6. Alexander F. The resurrection of the body / F. Alexander. - New York : Dell (Delta books), 1969. - 234 p.

7. Lowen A. Bioenergetic analysis : a mind-body therapy / A. Lowen, J. Zeig ed. // The evolution of psychotherapy. - New York, 1992.

8. Rolf I. P. Rolfing : the integration of human structures / I. P. Rolf. - Santa Monica : Denis-Landman, 1977.

9. Upledger J. E. Craniosacral Therapy / J. E. Upledger, J. D. Vredevoogd. - New York : Eeasland Press, 1983. - 367 p.

10. Режим доступа: http://www.osteodoc.ru/dfg.htm.

\section{Николай Мога. Гагмонизация мышечно-фасциальной системы детей раннего возраста со спастическим синдромом двигательных нарушений}

В статье подробно рассмотрен третий условный коррекционный вектор общей авторской реабилитационной стратегии в отношении детей раннего возраста со спастическим синдромом двигательных нарушений - методические возможности гармонизации их мышечно-фасциальной системы. Предварительно было проанализировано состояние главных парных миофасциальных линий через призму спастического синдрома: поверхностной фронтальной линии, поверхностной задней линии, двух латеральных линий, двух спиральных линий, двух парных линий рук. За основу коррекции состояния мышечного дисбаланса на фоне имеющегося спастического синдрома была взята диагонально-фасциальная гимнастика (ДФГ) Пака Дже Ву, с помощью которой гармонизируется состояние мыши - антогонистов. Главными техниками этой методики являются поочередное растяжение мыши, их сжатие, а затем скручивание по диагональными направлениями в разных сегментах тела при чередовании с центральными, срединными направлениями коррекционных воздействий. Такой подход напоминает спиралевидные движения и является универсальной структурной моделью развития жизни. Базовые методические положения ДФГ были адаптированы в соответствии с решением задач коррекции двигательных нарушений спастического типа у детей именно раннего возраста на основе бондингових техник и необходимой театрализации процесса коррекции. Именно это уникальное сочетание позволяет в значительной степени преодолеть имеющийся у детей этого возраста страх перед телесными манипуляциями и болевым синдромом, которые при этом возникают. Дополнительно была использована вибрационно-волновая техника упражнения с мышцами. С помощью адаптированного варианта диагонально-фасциальной гимнастики возможно достичь более высокой степени эффективности коррекции имеющихся двигательных нарушений спастического типа. Перспективы исследования этой проблемы находятся в русле поиска новых технических приемов адаптации ДФГк физической реабилитации детей раннего возраста в сочетании с телесным бондинговим фоном и на основе эмоционально-энергетической насыщенности двигательно-игровой деятельностью.

Ключевые слова: двигательные нарушения, мышечно - фасциальная система, диагональная гимнастика, коррекция, гармонизация.

Nikolai Moga. Gagmonization of the musculo-fascial system of young children with spastic syndrome of motor disorders

The article discusses in detail the third conditional correctional vector of the general author's rehabilitation strategy for young children with spastic syndrome of motor disorders - the methodological possibilities of harmonizing their musculo-fascial system. Previously, the state of the main paired myofascial lines was analyzed through the prism of spastic syndrome: the superficial frontal line, the superficial posterior line, two lateral lines, two spiral lines, two paired lines of hands. The basis for the correction of the state of muscle imbalance against the background of the existing spastic syndrome was taken diagonal fascial gymnastics (DFG) by Pac-Jee Woo, which harmonizes the state of the muscles - the antagonist. The main techniques of this technique are alternate stretching of the muscles, their compression, and then twisting along diagonal directions in different segments of the body when alternating with the central, middle directions of corrective actions. Such an approach resembles spiraling movements and is a universal structural model for the development of life. The basic methodological provisions of the FGD were adapted in accordance with the solution of the problems of correction of spastic-type motor disorders in young children, based on bonding techniques and the necessary theatricalization of the correction process. It is this unique combination that makes it possible to largely overcome the fear of bodily manipulations and pain that exists in children of this age. Additionally, vibration-wave technique exercises with muscles were applied. With the help of an adapted version of the diagonal fascial gymnastics, it is possible to achieve a higher degree of efficiency in correcting existing motor disorders of the spastic type. Prospects for the study of this problem are in line with the search for new techniques for adapting DFG to physical rehabilitation of young children in combination with a physical bonding background and on the basis of emotional and energetic saturation of motor and gaming activities.

Key words: motor disorders, musculo - fascial system, diagonal gymnastics, correction, harmonization. 